\title{
Koneista, metaforista ja työn yhteiskunnan todellisuuksista
}

Mannevuo, Mona: Ihmiskone töissä. Sotienjälkeinen Suomi tehokkuutta tavoittelemassa. Gaudeamus 2020, 326 sivua.

Sukupuolentutkimuksen oppiaineessa koulutuksensa saanut, affektitutkijana tutkijanuransa aloittanut Mona Mannevuo jatkaa tuoreimmassa suomenkielisessä monografiassaan suomalaisen työelämätutkimuksen parissa. Tällä kertaa aihealueena on tehokkuusihanteiden aatehistoria 1900-luvun puolivälin jälkeisestä Suomesta aina nykyaikaan asti. Mannevuo seuraa tehokkuuspuheen aatehistoriaa historiantutkija Walter Jacksonilta omaksumansa käsitteen, sosiaalisen insinööritaidon, kulttuurista muutosta tutkimalla. Mannevuo keskittyy tutkimuksessaan osoittamaan varsin ansiokkaasti jatkuvuuksia menneen ja nykyisen tehostamispuheen välillä, "jotta ymmärtäisimme, miksi olemme sellaisia kuin olemme" (s. 7).

Toinen teoksen keskeinen käsite on Kyla Schullerin biofilantropia. Mannevuon mukaan käsitteen avulla on mahdollista kuvata sosiaalihygienian eli väestön elinolojen kohentamisen vaikutuksia ja kytkeytymistä rationalisointiin, tieteeseen, modernisaatioon sekä edellä mainittuun sosiaaliseen insinööritaitoon. Mannevuo näkee, että Suomessa harjoitettu valistuksellinen kansanterveystyö ja muu sosiaalinen insinööritaito "on mahdollista tulkita osaksi Suomen 'amerikkalaistamista'". Työelämä todella oli kiivaan poliittisen sekä symbolisen kamppailun kohteena sotien jälkeen. Tutkimus onnistuu tuomaan uusia avauksia työelämän tutkimuksen kentälle: sotakorvausteollisuuden tutkimuksessa ei ole aiemmin keskitytty erityisesti työn tehostamisen aatehistoriaan tai rationalisointiajattelun kansainvälisiin tie- 
teellisiin kytköksiin, vaikka esimerkiksi Pauli Kettunen on suomalaista rationalisointia useissa teoksissaan analysoinutkin, minkä Mannevuo toki tuo esiin. Biofilantropisesti tarkastellen se, mikä yhdelle näyttäytyy positiivisena suunnitelmallisuutena, on toiselle valtion "puutarhanhoidollista siivoamista" vääristä oksista (s. 24).

Mannevuo näkee sosiaalisen insinööritaidon toimineen Suomessa käyttäytymistä ohjaavana työkaluna. Valtiojohtoisena se muistutti hänen mukaansa lasten kasvattamista tai kansalaisten näkemistä käytännön ratkaisuja kaipaavina ongelmina. Sodan jälkeen paimentamista vaativat erityisesti ne työkansalaiset, joilla oli vaikeuksia sopeutua teollisuustyön ja jälleenrakennuksen kiihkeään rytmiin. Raja kansalaisten hyvinvointia lisäävän tai oikeuksia rajoittavan politiikan välillä oli ohut, ja sen ylittäminen oli kohtuullisen helppoa. Mannevuon näkemys siitä, miten sotakorvausajan Suomi muistutti "suurta Pohjan prikaatia", jossa oikeusjärjestelmä saattoi asettua kansalaisia vastaan, on uskottava. Tämän Mannevuo näkee poikkeavan valistuksesta periytyvästä modernista länsimaisesta oikeuskäytännöstä. Teoksessa olisi voitu kuitenkin tuoda esille valistuksen kahtalaista luonnetta, sillä se sisältää taksonomista luokittelua, joka palvelee tehostamista.

Ihmiskone töissä avaa tarpeellisen ja yhteiskunnallisesti tärkeän keskustelun työelämästä. Kirja esittelee monipuolisesti tehokkuusajattelun eri osa-alueita: käsittelyyn pääsevät niin liikkeenjohdon tehostamisopit Fordista Tayloriin kuin myös niiden omaksuminen ja soveltaminen toisen maailmansodan jälkeisessä Suomessa. Aihetta syvennetään tutkimalla teollisuuden työnjohto-oppeja sotakorvausteollisuuden aikana, työterveysajattelun kehittämistä, työläisten luonneoppeja, työn sielullista hygieniaa, työelämän psykopaattiluokitteluita sekä tehokkuuspuheen käyttöönottoa niin sanotuissa työn tuuppausohjeissa.

Teoksen pääargumentti on, että nykyisen ja menneen tehostamispuheen välillä vallitsee jatkumo. Työmoraalin katoamista on murehdittu Suomessa yli sata vuotta, kun samalla on kummasteltu työväestön aatemaailmaa elämälle vieraana. Mannevuo osoittaa, miten reformisteille parempi yhteiskunta on aina sijainnut jossain toisaalla, paikassa, jossa on "tekemisen meininki, siistit tehtaat ja reipas työväki" (s. 283). Niin ikään teoksessa osoitetaan kiistattomasti, miten "mahojen oksien katkominen ja kieroon kasvaneiden taimien ojentaminen" ovat tehokkuuspuheen nykyisyyden historiaa ja edelleen osa nykyistä sosiaalista insinööritaitoa suomalaisessa yhteis- 
kunnassa. Tällaisessa ajattelumallissa yhteiskunta ymmärretään orgaaniseksi kokonaisuudeksi ja koneistoksi, jonka jokainen solu tulee optimoida vaikka väkisin tuupaten kohti täydellisyyttä. Tällainen yhteiskunnan kehittäminen saa poliittisen mielipiteen puolelleen, koska ristiriitaistenkin toimijoiden aikeet ovat hyvät, ja "nahjusten aktivoinnin" väitetään lisäävän yhteiskunnan hyviä kehiä. Nämä hyvät aikeet ja kehät hyödyttävät siten "nahjuksiakin". Samalla koko kansakunnan tuottavuus kasvaa. (s. 282.)

Mannevuon teoksen huomio siitä, että sotakorvausajalla lopullisesti Suomeen rantautunut tehokkuusajattelu on monimuotoistunut ja yksilöllistynyt, on äärimmäisen tärkeä analyyttisesti. Tavallisuuden hyve on muuttunut ainutlaatuisuuden ja erinomaisuuden yksilöllistetyksi hyveeksi. Mainio ja historiallisesti kelvollinen on myös tapa, jolla Mannevuo huomioi, kuinka helposti Yhdysvalloista Suomeen rantautunut moralistinen ajattelu sulautui suomalaiseen niukkuuden kulttuuriin (s. 284). Käännekohtana toiminutta 1990-luvun lama-aikaa olisi silti suonut käsiteltävän tarkemmin.

Lukuisten oivaltavien analyysien lisäksi kirjassa on myös joitakin selkeitä puutteita, jotka koskevat sekä käsitteitä ja kirjallisuutta että metodeja ja tuloksia. Mannevuo tekee oikein mainitessaan lähdepohjansa ohuuden. Valitettavasti tämä ei kykene poistamaan kaikkia niitä ongelmia, joita se hänen tutkimukselleen tuo. Kirjallisuudesta puuttuvat aivan keskeiset teokset: Raija Julkusen Uuden työn paradoksit sekä Jorma Kalelan Työttömyys 19oo-luvun suomalaisessa yhteiskuntapolitiikassa. Niiden avulla muutosta olisi hahmottanut selkeämmin.

Mannevuo kertoo tekevänsä aatehistoriallista tutkimusta mutta ei avaa sen metodista viitekehystä. Saattaa olla, että kustantaja on tätä edellyttänyt, jotta teosta ei kuormitettaisi käsitteellisesti liikaa. Menetelmän avausta teos olisi silti tarvinnut. Jo maininta siitä, että aatehistoriaa voi ajatella historioitsija Mark Bevirin tavoin tutkimuksena, jossa ollaan kiinnostuneita menneisyyden ihmisten ajattelusta ja siitä, miten joku toinen on aikoinaan tehnyt maailman ymmärrettäväksi, olisi avannut Mannevuon tekemät kiintoisat lähdelöydöt historiallisesti toimivammiksi ajallisessa perspektiivissä. Lukijalle jää osin epäselväksi se, miten käsitteet ovat muuttuneet, mitä ne ovat kuvanneet aikanaan tai kuvaavat nykyään, ja mikä niissä on samaa kuin aiemmin. Kontekstualisointi olisi osoittanut ajatustemme itseriittoisuuden harhaksi ja tehnyt sen ymmärrettäväksi näyttämällä, että valtaosa uskomuksistamme on lainoja aiemmilta sukupolvilta. Uskoakseni tähän Mannevuo teoksellaan pyrkii. 
Mannevuon etsiessä jatkumoita muutokset ja murrokset tuntuvat jäävän osin syrjään tai liian yleiselle tasolle. Tarkemmalla taustoituksella olisi samalla syntynyt aivan uudenlaisia analyyttisia mahdollisuuksia. Esimerkkinä voi mainita teoksen nimeen nostetun käsitteen "ihmiskone", jota selitetään viittaamalla urheiluvaikuttaja Lauri Pihkalan 1900-luvun alussa julkaisemaan teokseen. Kontekstiksi sille Mannevuo tarjoaa näkemyksen siitä, kuinka "tuolloin kansalaisia ympäröivät yhä useammin erilaiset koneet, jotka muodostuivat hiljalleen metaforaksi keholle". Mannevuo selittää Pihkalan näkemyksen vertaukseksi, joka samastaa ihmiskoneen ja höyrykoneen. Varmasti näin osittain onkin. Mannevuon mukaan Pihkalan tapa verrata ihmistä koneeseen on esimerkki siitä, miten 1800-luvun kuluessa ihmisruumis alettiin teollistumisen myötä mieltää fysiikan lakien säätelemäksi moottoriksi. Tämä ajatus perustuu Anson Rabinbachin klassikkoon Human Motor vuodelta 1992.

Rabinbachin teoksen analyysia olisi voinut viedä pidemmälle. Teos sisältää kokonaisen luvun siitä, miten aikakäsitys teollistumisen myötä muuttui, miten aika standardisoitiin ja miten teollistuminen edellytti universaalia jaettua aikakäsitystä sekä tämän mukaisia toisiinsa sidoksissa olevia maantieteellisiä aikavyöhykkeitä. Tämän huomioiminen olisi historiallistanut Mannevuon tehostamisanalyysia ja auttanut häntä avaamaan tehostamisen keskeisen ydinongelman, joka nyt jää taustalle. Jos teoksessa olisi mainittu työn ja pääoman sekä tuottavuuden jakautumisen ikuinen ongelma kapitalistisissa yhteiskunnissa, tästä olisi voinut jatkaa ajattelua vaikkapa siihen, että koneesta puhuttaessa ei välttämättä ole aina ollut kyse metaforasta, vaan ruumiin toiminnot voidaan mieltää koneellisesti ilman metaforia olematta kritiikittömiä suhteessa tehostamiseen.

Työelämä, joka kapitalismin lisäksi nyt otetaan teoksessa annettuna, olisi kaivannut tarkempaa kriittistä analyysia suunnassa, johon Mannevuo pyrkii. Työn takana on aina ihminen ja hänen kokemuksensa elämästä ja sen mielekkyydestä. Jos työn ja ihmisyyden suhdetta haluaa analysoida tarkemmin, tulisi pohtia myös sitä, miksi työelämä kokonaisuudessaan on sellainen uskomusjärjestelmä kuin se nykyään on. Miksi uskomme siitä lehdistössä esitetyt väitteet niin herkästi, että ajattelemme ihmiskoneen olevan ainoastaan tietynlainen ja työttömyyden tai menestymisen olevan ihmisen omaa syytä, vaikka kyse on aina ensisijaisesti yhteiskunnallisista olosuhteista ja niiden tuottamista rakenteista? 
Mannevuon teos on toimiva lisä suomalaiseen työelämätutkimukseen. Toivottavasti sen teemat jatkuvat työelämää koskevassa tutkimuksessa.

\section{Kirjoittaja}

Ilkka Levä, FT, dos., Helsingin yliopisto

sähköposti: ilkka.leva@helsinki.fi 